\title{
Rain research with disdrometers: a bibliometric review
}

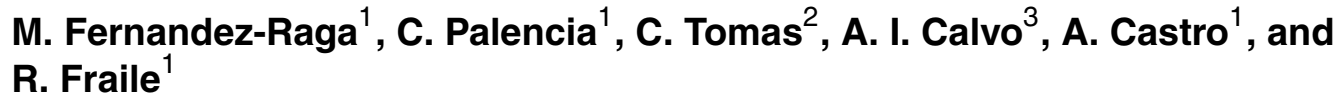

${ }^{1}$ Physics Department, IMARENAB, University of Leon, Leon, Spain

${ }^{2}$ Department of Atmospheric Physics, University of Salamanca, Salamanca, Spain

${ }^{3}$ CESAM, University of Aveiro, Aveiro, Portugal

Received: 28 August 2011 - Accepted: 12 September 2011 - Published: 23 September 2011 Correspondence to: R. Fraile (roberto.fraile@unileon.es)

Published by Copernicus Publications on behalf of the European Geosciences Union.
Rain research with disdrometers: a bibliometric review

M. Fernandez-Raga et al.

\section{Title Page}

Abstract Introduction

Conclusions References

Tables Figures

14

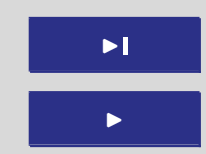

Back

Close

\section{Full Screen / Esc}

Printer-friendly Version

Interactive Discussion

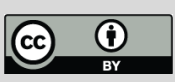




\section{Abstract}

This study analyses the research on disdrometers based on published studies. To do so, a wide data base of bibliographic references has been used: the Web of Science (published by Thomson Reuters). The search was carried out for all of the articles 5 whose "TOPIC" was disdrometer. The more than 300 articles found were analysed according to various criteria: countries with research using disdrometers; publication dates; evolution of the number of articles; concepts studied and research lines followed in each article; and finally, a bibliometric analysis of the more than 60 journals where these articles have been published. Since 1963, there has been an increase in the number of articles published on disdrometers, which in the last $20 \mathrm{yr}$ has been more than ten times higher than the increase in the number of articles on meteorology.

\section{Introduction}

Rain is a natural phenomenon that has always interested humanity and which has been the subject of numerous research studies (Ciach and Krajewski, 2006; Krajewski et al., 2006; Stephens and Kummerow, 2007). However, the detailed study of its most representative physical parameters and the modelling of its behaviour are still difficult today due to the localised nature of precipitation, and the impossibility of comparing two equal events (Ciach et al., 2007).

At present, global climate studies are focusing their attention on rainfall distributions, seeking to identify how they can affect the current and future weather in each specific location (Bartley et al., 2006). The consequences of convective episodes have also been studied, both in terms of the soil erosion they cause (Friedel et al., 2006; Agnese et al., 2006), and interferences in communications (Hitschfeld and Bordan, 1954), and in hydrological studies of reservoirs and dams, through the return periods (Hennessy 25 et al., 1997).
AMTD

4, 6041-6068, 2011

Rain research with disdrometers: a bibliometric review

M. Fernandez-Raga et al.

\section{Title Page}

Abstract

Introduction

Conclusions

Tables

References

Figures

14

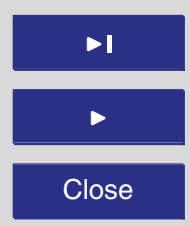

Back

Close

\section{Full Screen / Esc}

Printer-friendly Version

Interactive Discussion 
By studying the characteristic physical parameters of rainfall, it is possible to obtain a physical and dynamic description of rain, and therefore achieve a greater understanding of the impact of its intensity and energy (LeBissonnais, 1996). Efforts to increase the precision of data on raindrop size have progressed in recent decades:

5 Nueberger (1942) studied European research in terms of the comparison of raindrop sizes and their corresponding instrumentation.

The first attempts to measure raindrop sizes date from 1895, when Wiesner (1895) published the description of a method consisting of using a sheet of absorbent paper covered with a water-soluble dye, which was exposed to rainfall for a few seconds.

10 After patting the paper, the drops left permanent marks on it because of the dye. He considered that the diameter of the marks would only depend on the size of the raindrop, although in reality they depend on the thickness of the paper and the velocity at which the drop falls on the absorbent layer. Also, the humidity of the paper affects the measurement of the diameters. One major problem affecting this method is that 15 when large sized drops hit the paper, they can break up and spatter over it, making it impossible to determine their size. With some modifications, such as automating the analysis using software, its objectivity could be improved, adding a further benefit to its low cost and ease of use (Cerdá, 1997; Cruvinel et al., 1999; Salles and Poesen, 1999).

20 Another traditional way of measuring raindrop size is the flour method, which today has been replaced by using plaster (Ries et al., 2009). This was originally presented by Bentley (1904) and subsequently modified by Laws and Parsons (1943). The process consists of allowing the raindrop to fall on a layer of uncompacted flour between two or three centimetres deep. The layer is held in a surface container with a diameter of 10 25 centimetres, which is generally exposed to the rain for a few seconds. The raindrops are retained in this two or three centimetre deep layer, and are not collected until a hard, dry paste is formed as a result of the raindrop interacting with the flour. These dough pellets are then removed, classified according to their sizes and photographed for later analysis. The process of classifying the raindrops by size consists of using a

\section{AMTD}

$4,6041-6068,2011$

\section{Rain research with disdrometers: a bibliometric review}

M. Fernandez-Raga et al.

\section{Title Page}

Abstract Introduction

Conclusions

Tables

References

Figures

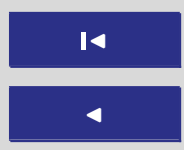

Back

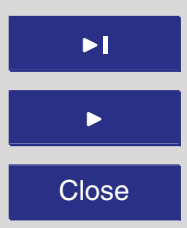

Full Screen / Esc

Printer-friendly Version

Interactive Discussion

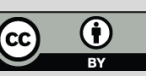


series of standard sieves to group the dough pellets into different sizes.

The instrument has to be calibrated, as the real size of the raindrop does not correspond exactly to the size of the dough pellet formed after the impact. This process consists of allowing drops of a known size to fall onto the instrument in order to calcu-

5 late their correspondence with the dough pellet. The disadvantages of this method are that it is very laborious, overlapping can occur (several drops can fall onto the same point), and it is difficult to create the smallest drops for calibration purposes.

Jones (1959) developed another method known as the raindrop camera, which consists of two cameras placed close together that are synchronised to take two photos si10 multaneously of the raindrop from two perpendicular angles (east-west or north-south). This method makes it possible to obtain a three-dimensional image of the shape of the raindrops, and from there to calculate the measurement of the raindrops, although with some complications in the calculations which make them difficult to compare with other studies.

15 Until the development of the Illinois camera (Mueller, 1966) it was not possible to carry out an extensive study of raindrop sizes in the field. The data from the camera, gathered in a series of locations in the USA and Indonesia, have been used in a considerable amount of erosion research (Kinnell et al., 1996; Mclsaac et al., 1990; Fernandez-Raga et al., 2010). The camera is capable of capturing raindrops in an area of $1 \mathrm{~m}^{3}$ of air every $10 \mathrm{~s}$. However, apart from being very expensive, it suffers from superimposition problems. Almost simultaneously, Clardy and Tolbert (1961) referred to the disdrometer for the first time as an instrument that could possibly be used for measuring the sizes and velocities of raindrops. The disdrometer they described consisted of a phototube that captured the number of raindrops passing through the sampling region, in each range of sizes. It was found that the distribution of sizes quite closely fit the distribution hypothesised by Laws and Parsons (1943).

One of the most widely known instruments is the disdrometer based on microphonic measurements. It was developed by Joss and Waldvogel (1967). A microphone sensor covering an area of $50 \mathrm{~cm}^{2}$ converts the vertical momentum of the impact of the
AMTD

$4,6041-6068,2011$

Rain research with disdrometers: a bibliometric review

M. Fernandez-Raga et al.

\section{Title Page}

Abstract Introduction

Conclusions

Tables

References

Figures

14

$>$ I

4

Back

$\checkmark$

Close

Full Screen / Esc

Printer-friendly Version

Interactive Discussion

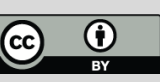


raindrop into electrical impulses, which are processed and shown on a screen or printed in tables that show the measurements obtained. This system assumes that the raindrop is spherical, and that the descent speed is the terminal velocity. The instrument detects raindrops with diameters of between 0.3 and $5 \mathrm{~mm}$, and can record a 5 maximum of 190 impacts per second in the sampling area.

Some years later, the first electromagnetic-type systems appeared, also known as optical systems, in which the electrical pulse is not produced by a vertical impact, but instead by the raindrop passing through a laser beam. Optical disdrometers have evolved constantly since the 1980 s and 1990 s, becoming more sensitive, more pre10 cise, and more capable of distinguishing between raindrop sizes by using different wavelengths and improved techniques (Ries et al., 2009). A wide range of optical measurement strategies have been developed (Knollenberg, 1976; Donnadieu, 1980; Illinworth and Stevens, 1987; Illinworth et al., 1990). For example, the spectrometer referred to as the Particle Measuring System (PMS) (Knollenberg, 1970; Joe and List, 15 1987) or the Ground Based Precipitation Probe (PMI Model GBPP-100), determines the size of the particles that cross through a laser beam based on the shadow cast on a series of photodiodes arranged in a line. The optical spectro-pluviometer (OSP) takes measurements from raindrops falling through a parallel beam of ultraviolet light (Hauser et al., 1984). Also, the Laser Precipitation Monitor (Thies Clima), which emits 20 a laser beam at $785 \mathrm{~nm}$, determines the fraction of the electromagnetic energy intercepted by the raindrop. The models also offer the possibility of measuring the descent velocity of the raindrop, as with the Parsivel Laser Optical Disdrometer.

The need to have samples of the distribution of raindrop sizes in a large volume has been resolved by using radar measurements of the velocity spectra generated by the raindrops scattered in volume on the sensor (Rogers, 1967). One method of this type is the Precipitation Occurrence Sensor System, POSS, which is a static X-band radar that points upwards and determines the reflectivity of the raindrops when they are falling a few centimetres above the device (Sheppard, 1990). Another contribution to measuring raindrops is the Micro Rain Radar, an instrument that is halfway between

\section{AMTD}

$4,6041-6068,2011$

\section{Rain research with disdrometers: a bibliometric review}

M. Fernandez-Raga et al.

\section{Title Page}

Abstract Introduction

Conclusions

Tables

References

Figures

14

$\Delta \mathbf{I}$

4

Back

$\checkmark$

Close

Full Screen / Esc

Printer-friendly Version

Interactive Discussion

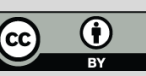


a disdrometer and radar system. It combines the reflectivity measurement at different heights with the descent velocity of the raindrops by the Doppler effect (Leijnse and Uijlenhoet, 2010). Some examples of disdrometers are shown in Fig. 1.

The increasing proliferation of research carried out with the help of disdrometers in 5 recent decades invites an evaluation of the literature in order to obtain a perspective that serves to guide future studies. Specifically, the aim of this article is to examine the evolution of studies carried out with disdrometers based on the documents that have been published, and to analyse the characteristics of these publications.

\section{Material and methods}

10 The Web of Science (WOS) has been used for this study. This is one of the most prestigious bibliographic databases for consultation purposes. The main appeal of this database is the versatility obtained from the combination of data offered. The general search for a topic can be refined by selecting publications for their area of scientific interest, i.e. the branch of science with which the study is concerned, or by the type of 15 document (articles, abstracts, proceedings, letters, etc.). However, the search can be refined much more by entering a specific author, journal or even a conference where it was published. Searches can also be made by selecting the country and language in which the article was written. Naturally, the documents can be selected chronologically, limiting the search period.

20 All of these possibilities have made it possible to create a database on the use of disdrometers, and to carry out a detailed analysis of the evolution of authors, ideas, journals and countries over time. Data have been consulted up to 7 January 2011. This database contains more than $3.8 \times 10^{7}$ scientific documents included in the Science Citation Index Expanded (SCI-EXPANDED) from 1945 to the present, of which
381 documents include the word disdrometer*, where the asterisk is a wildcard for any letter or group of letters (this was done mainly to include the plural). Out of all of these publications, according to the general category which includes the theme of

\section{AMTD}

4, 6041-6068, 2011

Rain research with disdrometers: a bibliometric review

M. Fernandez-Raga et al.

\section{Title Page}

Abstract Introduction

Conclusions

Tables

References

Figures

14

$\Delta$

4

Back

Close

\section{Full Screen / Esc}

Printer-friendly Version

Interactive Discussion 
the publication - the "General Categories" - this group of 381 publications would be divided into those that cover themes of Science and Technology, which represent the vast majority, with 365 publications, and those of wider social interest, called Social Sciences, with a total of 15 . This last group of publications uses the disdrometer in

\section{Results}

Until 7 January 2011, the database contains a total of 381 publications that contain the word disdrometer ${ }^{*}$, of which the vast majority are articles (294), although there are also presentations at proceedings (79), abstracts in meetings (6), letters (4) and notes (2). 10 These publications were written by a total of 214 authors, from 26 countries. A total of 93 of these documents contain the word disdrometer in their title, which indicates the relevance of the device in their research.

The subject matter covered by these articles belongs to the Subject Category of Meteorology and Atmospheric Sciences, which contains 280 of the previously mentioned 15 publications. This is a much higher number than the rest of the areas in which studies using disdrometers have been published. For example, it is more than twice the 127 in Geology, which is the closest Subject Category to it; it is 2.5 times higher the number of articles published in the area of Engineering, with 112 publications, and 7 times more than the publications corresponding to Geochemistry and Geophysics, Remote Sensing or Telecommunications, with 40,39 and 35 documents respectively.

\subsection{Evolution}

After its appearance in the 1960s, the disdrometer was firstly described by Clardy and Tolbert (1961) (curiously, this article is not included in the WOS database). The evolution of the publications can be seen in Fig. 2 . The first article from the WOS, the only one in the 1960s, is by Joss and Waldvogel (1967). In the 1970s, 13 articles were

\section{AMTD}

$4,6041-6068,2011$

\section{Rain research with disdrometers: a bibliometric review}

M. Fernandez-Raga et al.

\section{Title Page}

Abstract

Introduction

Conclusions

References

Tables

Figures

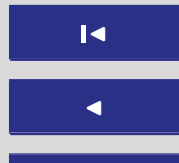

Back

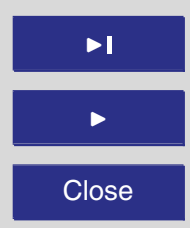

Full Screen / Esc

Printer-friendly Version

Interactive Discussion 
published (Fig. 3), which mainly offer a more detailed description of disdrometers, how they work and improvements in their design.

The 1980s were characterised by a general downturn with respect to the number of publications in previous years, with only 6 articles. However, there is an emphasis

5 on a more detailed search for applications of the disdrometer, as comparisons had begun with radars, and studies applied to zones with interesting characteristics, such as tropical storms. Also, the articles largely analysed the evolution of reflectivity as a characteristic parameter of different types of rain.

Yet it would not be until the 1990s when the field of applications of the disdrometer 10 was truly extended, with a much larger number of publications: 64 . Topics were studied as varied as the oscillations and polarisation of raindrops, modelling or the distribution of raindrop sizes. This decade also marked the appearance of less theoretical applications, such as erosion studies, and studies applied to evaluate risks caused by extreme weather types, and even the economic implications, as demonstrated by studies on the attenuation and dispersion of telecommunications waves.

From 2001 onwards, the number of publications on disdrometers grew exponentially, to the point of 296 documents being published as of December 2010. In reality, all of these articles aim to complete and develop the areas that had been opened previously, although the use of the disdrometer is clear and well established for its scientific application in numerous fields. In terms of the number of publications, the most frequent are articles based on reflectivity, comparisons with radar and stations, modelling, erosion, wave attenuation, and distribution of drop sizes.

\subsection{Source of the publications}

A geographic analysis shows that research with disdrometers has been carried out in 2525 countries, with the majority $-58.7 \%$ of the total - published in the USA. In general, it can be seen that the geographic distribution of the use of the disdrometer is closely associated with the problems caused by an extreme abundance or scarcity of rainfall. Outside of the USA, the Mediterranean countries (France, Italy, Spain, Greece and

\section{AMTD}

$4,6041-6068,2011$

\section{Rain research with disdrometers: a bibliometric review}

M. Fernandez-Raga et al.

\section{Title Page}

Abstract Introduction

Conclusions

Tables

References

Figures

14

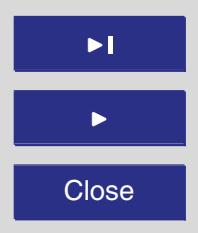

Back

Close

\section{Full Screen / Esc}

Printer-friendly Version

Interactive Discussion 
Israel) represent nearly $21 \%$ of the total scientific production. Central Europe (Germany, the Netherlands, Switzerland, Austria and Poland) have also dedicated efforts to research in this area, with publications from these countries representing more than $14 \%$ of the total.

5 Other countries with an important volume of publications are Japan (with $7.4 \%$ ), Canada (with $6.6 \%$ ) and England (with $4.1 \%$ ). The case of India is of special interest due to the frequent torrential climatic changes in its climate: its publications on disdrometers represent $4.4 \%$ of the world total. Australia and New Zealand have published close to $4 \%$ of the total, and finally other countries in Asia, Africa and the 10 Americas offer minimum percentages. Figure 4 shows the location of all of the countries which have published scientific articles on disdrometers, with the percentages in comparison to the world total.

Before ending this section, it should be noted that the total of the percentages shown in the previous paragraphs is not 100, as there are collaborations between different 15 countries. An article with contributors from two or more countries is assigned to each of the countries represented.

The pioneering countries - those that published the first documents on disdrometers - are shown in Fig. 5, which also shows the year in which they were first published and the number of articles prior to 1980.

\subsection{Main authors and citations}

Out of the 612 authors who have written the publications included in this database, the author who has written the most on the disdrometer is Bringi, with a total of 29 articles. His career was based on comparing data from the disdrometer with different types of radar, and even with other instruments and satellite data (Fig. 6). His articles consist of research contrasting data with the disdrometer, the analysis of reflectivities, studies of drop size distributions, developing rainfall models and even measurements of drop sizes in wind tunnels.

\section{AMTD}

4, 6041-6068, 2011

\section{Rain research with disdrometers: a bibliometric review}

M. Fernandez-Raga et al.

\section{Title Page}

\section{Abstract}

Introduction

Conclusions

Tables

References

Figures

14

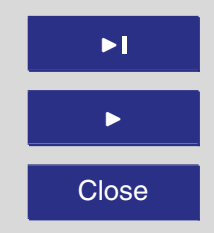

Back

Close

\section{Full Screen / Esc}

Printer-friendly Version

Interactive Discussion 
However, and without detracting any merit from Bringi's enormous production in terms of articles, a study of the relevance of the articles published to date on disdrometers indicates that Tokay is a leading researchers, found in 5 of the 10 most cited articles, with his publications occupying first, second, fourth, seventh and ten place. In 5 the analysis of the article that has been cited the most, this once again corresponds to Tokay and Short (1996), an article cited 177 times on the drop spectrum in rainfall of a stratiform origin versus that of a convective origin (classification of a tropical storm as convective or stratiform according to its drop size distribution). This is surprising, as in the majority of cases, each with 60 or 70 citations, the most frequently cited articles 10 are on the distribution of drop sizes and their comparison with radar. However, the most widely cited article is a new subject in the most widely cited publications. It also has the highest citation index for all of the documents, with more than 12.5 citations per year. Another innovative subject in this list of the most cited articles is in eleventh place, the calculation of kinetic energy by Van Dijk et al. (2002), or the sixteenth place, corresponding to studies on irregularities in drop shapes.

The number of publications has clearly increased since the 1990s, revealed in the growth in the number of experiments. As would be expected, an increase has also been seen in the number of citations, as shown in Fig. 7, although in this case with a delay of $5 \mathrm{yr}$ in the start of this growth with regard to the increase in the number of 20 publications.

\subsection{Journals}

With regard to specific journals, these articles have mainly been published in 2: The Journal of Atmospheric and Oceanic Technology and The Journal of Applied Meteorology, with 17.8 and $19.1 \%$ of the publications respectively. In these journals, the 25 number of articles published between the 1990s and the first decade of the twenty-first century grew have increased by $250 \%$ (Fig. 8).

On examining the citations, we find that these two journals contain the majority: The Journal of Applied Meteorology or its successor, The Journal of Applied Meteorology 6050
AMTD

$4,6041-6068,2011$

Rain research with disdrometers: a bibliometric review

M. Fernandez-Raga et al.

\section{Title Page}

Abstract Introduction

Conclusions

Tables

References

Figures

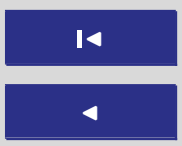

$>$ I

Back

Close

Full Screen / Esc

Printer-friendly Version

Interactive Discussion
$>$

(1)

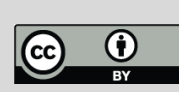


and Climatology, representing $25.1 \%$ of all citations, followed by The Journal of Atmospheric and Oceanic Technology with $21.4 \%$. Also, the 3 most widely cited articles are publications from The Journal of Applied Meteorology, and from the 10 most cited articles, 5 are from this same journal.

$5 \quad$ Finally, it must be noted that even though the WOS database is a high-quality source and includes the most important journals in the field, there are many other publications that are not included in this database: theses, books, articles with a non-international character, non-periodical publications, etc. This paper does not analyse all of the existing articles on disdrometers, but it does include a sufficiently representative sample of 10 the articles with the highest quality standards enabling us to draw general conclusions on the trend in this particular field.

\subsection{Evolution of the use of disdrometers}

During the first decade, the applications of the disdrometer were restricted to the design and improvement of the instrument (Joss and Waldvogel, 1967), which were gradually 15 developed during the 1970s. The majority of the articles from this period dealt with comparisons between two disdrometers, or between disdrometers and rain gauges. But it was not until the 1980s when work began on comparing radar data with surface data obtained by disdrometers, with applications in the study of tropical storms, and the evolution of reflectivity. The 1990s saw new progress in studies based on oscillations 20 of small drops, and the development of the first theoretical models on the distribution of drop sizes, with the help of polarised radars.

However, the real development of applications other than those strictly applied to meteorology appeared at the end of the 1990s and in the early twenty-first century. Different fields of research have gradually taken shape in which the information de25 tected by this instrument may be crucial. And example of this is the field of erosion, in which the disdrometer can be highly useful, detecting drop sizes and intensities with high erosive power; it has also been used in hydrological models, or even in hazard models for different types of storms or in the attenuation of telecommunication signals.

\section{1}

\section{AMTD}

$4,6041-6068,2011$

\section{Rain research with disdrometers: a bibliometric review}

M. Fernandez-Raga et al.

\section{Title Page}

Abstract

Introduction

Conclusions

Tables

References

Figures

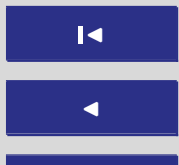

Back

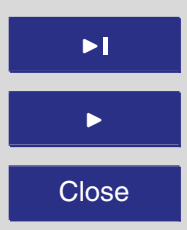

Full Screen / Esc

Printer-friendly Version

Interactive Discussion 


\subsection{Keywords and topics}

A review has been carried out of the keywords that appear the most in the documents that have been found (Table 2). Logically, the vast majority of the articles -308 in total - are defined by the keywords "Drop size distribution", which is what the disdrometer 5 measures. This keyword is followed, to a significantly lesser extent, by the keyword "radar", for two main reasons: firstly, that radar is the most widely used instrument in precipitation studies and is the instrument of reference for cloud behaviour studies, as well as their subsequent evolution; and secondly, because the disdrometer is a measurement instrument located on the surface of the terrain, it provides complementary 10 data to those provided by radar. Other keywords that are logically found in large numbers are "precipitation" or "rainfall and disdrometer".

From here, the keywords indicate other areas in which work has been carried out with disdrometers, such as studying drop shape, studying cloud classification, climatic models and precipitation parameters in general, and their classification. In some articles 15 we find words that refer to specific instruments, such as the Waldvogel or bidimensional disdrometer, and words that refer to the study of propagation and soil erosion. It is interesting to note that there are 63 articles that refer to the use of Joss-Waldvogel disdrometers, compared to 54 on optical disdrometers.

By carrying out a new search for articles that used two words simultaneously in the TOPIC field (one of which was disdrometer ${ }^{\star}$ ), it was possible to study the evolution of the contents, by analysing from which year the disdrometer was used in this field of research. The most frequently used combination of words was "radar + disdrometer", as would be expected. These two words have been used jointly since 1972, and from them they have continued to be used in 271 of the 366 articles that contain "disdrometer" as of "rainfall + disdrometer", found in 241 publications. The success of these combinations lies in the fact that the purpose of the disdrometer is similar to a degree to that of radar: to be able to quantify and study rainfall phenomena.
AMTD

4, 6041-6068, 2011

Rain research with disdrometers: a bibliometric review

M. Fernandez-Raga et al.

\section{Title Page}

Abstract

Conclusions

Tables

References

Figures

14

$\Delta$

4

Back

Close

\section{Full Screen / Esc}

Printer-friendly Version

Interactive Discussion 
By 1976 two new words are combined that precisely indicate the objective that was sought with the invention of the disdrometer: "raindrop + disdrometer", which has been repeated 192 times since it first appeared, together with the combination "reflectivity + disdrometer"”, which appeared slightly later (in 1978), and is found in 187 articles.

In the 1980s, there was little scientific innovation in this field. The most original aspect lies in defining a geographic or climatic area in which to study the combinations that have already been commented. Therefore, the combination "tropical + disdrometer"” is the most widely repeated (on 77 occasions after 1987).

From the 1990s onwards (more specifically, since 1991), new research concepts 10 have been dealt with: "drop size distribution* + disdrometer" or "break up + disdrometer" have respectively appeared on 194 and 20 occasions since then. Also, new horizons were opened in the uses of the disdrometer, such as measurements for calculating vertical velocity, modelling and measuring wind speeds, with 30,121 and 59 articles respectively. A total of 78 articles have been published on the attenuation of electromagnetic waves in the field of telecommunications. Subsequently, 44 articles have been published since 1999 with the topics "propagation + disdrometer". In the case of erosion, a total of 9 articles have been published for "erosion + disdrometer", the first in 1993. In all likelihood this group could also contain the articles on "kinetic energy + disdrometer", consisting of a further 19 articles since 1996. A final point of interest is the classification of rainfall, as demonstrated by the 87 articles whose topic contains "convective + disdrometer" and the 83 for "stratiform + disdrometer", which began to be a point of interest in 1993 and 1996 respectively.

The main areas researched using disdrometers are shown in Table 3. In summary, the largest number refer to meteorological research, with 226 articles, which are reduced to one third in the following area of interest (engineering and geology). More specific areas, such as the use of models, do not appear until 1991, or erosion (from 1998), hydrology (1999) or wave attenuation (2003).
AMTD

$4,6041-6068,2011$

\section{Rain research with disdrometers: a bibliometric review}

M. Fernandez-Raga et al.

\section{Title Page}

Abstract Introduction

Conclusions

Tables

References

Figures

14

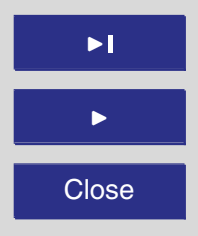

Back

Close

\section{Full Screen / Esc}

Printer-friendly Version

Interactive Discussion

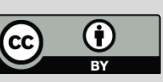




\section{Conclusions}

Over the years the technique for measuring raindrop size and velocity has improved greatly, from manual and quite unreliable methods to automatic methods - optical disdrometers or devices employing the moments method. On studying the publications 5 included in the WOS, we have found that $47 \%$ of the publications on disdrometers appear in only 2 journals: The Journal of Atmospheric and Oceanic Technology and The Journal of Applied Meteorology. These 2 journals also include most of the citations. Proportionally, the most cited articles have also been published in The Journal of Atmospheric and Oceanic Technology and The Journal of Applied Meteorology. The 10 author with the highest number of articles using disdrometers is Bringi, with 28 articles. However, Tokay is the author of the articles with the highest impact.

The main fields that make use of disdrometers are, above all, meteorology, hydrology, rain parameter modelling and soil erosion. The disdrometer is a device which is being used increasingly in many different countries, with up to 40 articles published 15 in 2009. With these precedents, it is expected that research with disdrometers will continue to increase, as the applications for the data provided by these measurement instruments has also multiplied.

Acknowledgements. This study was supported by the Regional Government of Castile and Leon (Grant LE039A10-2) and the Spanish Ministerio de Ciencia e Innovación (Grant 20 TEC2010-19241-C02-01).

\section{References}

Agnese, C., Bagarello, V., Corrao, C., D'Agostino, L., and D'Asaro, F.: Influence of the rainfall measurement interval on the erosivity determinations in the Mediterranean area, J. Hydrol., 329, 39-48, 2006.

25 Bartley, R., Roth, C. H., Ludwig, J., McJannet, D., Liedloff, A., Corfield, J., Hawdon, A., and Abbott, B.: Runoff and erosion from Australia's tropical semi-arid rangelands: influence of ground cover for differing space and time scales, Hydrol. Process., 20, 3317-3333, 2006.

6054
AMTD

$4,6041-6068,2011$

Rain research with disdrometers: a bibliometric review

M. Fernandez-Raga et al.

\section{Title Page}

Abstract

Introduction

Conclusions

Tables

References

Figures

14

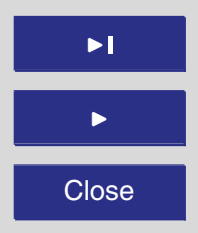

Back

Close

\section{Full Screen / Esc}

Printer-friendly Version

Interactive Discussion 
Bentley, W. A.: Studies of raindrops and raindrop phenomena. Mon. Weather Rev., 32, 450456, 1904.

Cerda, A.: Rainfall drop size distribution in the Western Mediterranean Basin, Valencia, Spain, Catena, 30, 169-182, 1997.

5 Ciach, G. J. and Krajewski, W. F.: Analysis and modeling of spatial correlation structure in small-scale rainfall in Central Oklahoma, Adv. Water Resour., 29, 1450-1463, 2006.

Ciach, G. J., Krajewski, W. F., and Villarini, G.: Product-error-driven uncertainty model for probabilistic quantitative precipitation estimation with NEXRAD data, J. Hydrometeorol., 8, 1325-1347, 2007.

10 Clardy, D. E. and Tolbert, C. W.: Electronic Disdrometer, Rev. Sci. Instrum., 32, 916-920, 1961.

Cruvinel, P. E., Vieira, S. R., Crestana, S., Minatel, E. R., Mucheroni, M. L., and Neto, A. T.: Image processing in automated measurements of raindrop size and distribution, Comput. Electron. Agr., 23, 205-217, 1999.

Donnadieu, G.: Comparison of Results Obtained with the Vidiaz Spectropluviometer and the 15 Joss-Waldvogel Rainfall Disdrometer in a Rain of a Thundery Type, J. Appl. Meteorol., 19, 593-597, 1980.

Fernandez-Raga, M., Fraile, R., Keizer, J. J., Teijeiro, M. E. V., Castro, A., Palencia, C., Calvo, A. I., Koenders, J., and Marques, R. L. D.: The kinetic energy of rain measured with an optical disdrometer: An application to splash erosion, Atmos. Res., 96, 225-240, 2010.

20 Friedel, S., Thielen, A., and Springman, S. M.: Investigation of a slope endangered by rainfallinduced landslides using 3D resistivity tomography and geotechnical testing, J. Appl. Geophys., $60,100-114,2006$.

Hauser, D., Amayenc, P., Nutten, B., and Waldteufel, P.: A new optical instrument for simultaneous measurements of raindrop diameter and fall speed distribution. J. Atmos. Ocean. Tech., 25 1, 256-269, 1984.

Hennessy, K. J., Gregory, J. M., and Mitchell, J. F. B.: Changes in daily precipitation under enhanced greenhouse conditions, Clim. Dynam., 13, 667-680, 1997.

Hitschfeld, W. and Bordan, J.: Errors Inherent in the Radar Measurement of Rainfall at Attenuating Wavelengths, J. Meteorol., 11, 58-67, 1954.

30 Illingworth, A. and Stevens, C. J.: An optical disdrometer for the measurement of raindrop size spectra in windy conditions, J. Atmos. Ocean. Tech., 4, 411-421, 1987.

Illingworth, A. J., Hauser, D., and Amayenc, P.: A Comparison of Optical Shadowgraph Instruments for Measuring Raindrop-Size Spectra, J. Atmos. Ocean. Tech., 7, 175-176, 1990.
AMTD

$4,6041-6068,2011$

\section{Rain research with disdrometers: a bibliometric review}

M. Fernandez-Raga et al.

\section{Title Page}

Abstract

Conclusions

References

Tables

Figures

14

$>1$

4

Back

$\checkmark$

Close

\section{Full Screen / Esc}

Printer-friendly Version

Interactive Discussion 
Joe, P. I. and List, R.: Testing and performance of two-dimensional optical array spectrometers with greyscale, J. Atmos. Ocean. Tech., 4, 139-150, 1987.

Jones, D. M. A.: The shape of raindrops, J. Meteorol., 16, 504-510, 1959.

Joss, J. and Waldvogel, A.: A Spectrograph for Raindrops with Automatic Interpretation, Pure Appl. Geophys., 68, 240-246, 1967.

Kinnell, P., Ramos, M. C., and Uson, A.: Method-induced variations in soil erodibility in erosion experiments with rain-impacted flow, Aust. J. Soil Res., 34, 715-720, 1996.

Knollenberg, R. G.: The optical array: an alternative to scattering or extinction for airbone particle size distribution, J. Appl. Meteorol., 9, 86-103, 1970.

10 Knollenberg, R. G.: Three new instruments for cloud physics measurements: the 2-D spectrometer, the forward scattering Spectrometer probe and the active scattering aerosol spectrometer, International Conference on Cloud Physics, Boulder, American, Meteorological Society, 544-561, 1976.

Krajewski, W. F., Kruger, A., Caracciolo, C., Gole, P., Barthes, L., Creutin, J. D., Delahaye, J. 15 Y., Nikolopoulos, E. I., Ogden, F., and Vinson, J. P.: DEVEX-disdrometer evaluation experiment: Basic results and implications for hydrologic studies, Adv. Water Resour., 29, 311-325, 2006.

Laws, J. O. and Parsons, D. A.: The relation of raindrop-size to intensity, Transactions-American Geophysical Union, 24, 452-460, 1943.

20 LeBissonnais, Y.: Aggregate stability and assessment of soil crustability and erodibility. Theory and methodology, Eur. J. Soil Sci., 47, 425-437, 1996.

Leijnse, $H$. and Uijlenhoet, R.: The effect of reported high-velocity small raindrops on inferred drop size distributions and derived power laws, Atmos. Chem. Phys., 10, 6807-6818, doi:10.5194/acp-10-6807-2010, 2010.

Mclsaac, G. F., Mitchell, J. K., and Hirschi, M. C.: Contour and Conservation Tillage for Corn and Soybeans in the Tama Silt Loam Soil - Hydraulics and Sediment Concentration, Transactions of the ASAE, 33, 1541-1550, 1990.

Mueller, E. A.: Radar cross sections from drop size spectra, University of Illinois, 1966.

Neuberger, H.: Notes of Measurement of Rain-drop Sizes, B. Am. Meteorol. Soc., 23, 247-276, 1942.

Ries, J. B., Seeger, M., Iserloh, T., Wistorf, S., and Fister, W.: Calibration of simulated rainfall characteristics for the study of soil erosion on agricultural land, Soil Till. Res., 106, 109-116, 2009.

\section{AMTD}

4, 6041-6068, 2011

\section{Rain research with \\ disdrometers: a \\ bibliometric review}

M. Fernandez-Raga et al.

\section{Title Page}

Abstract

Introduction

Conclusions

References

Tables

Figures

14

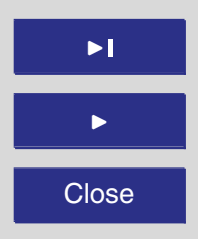

Back

Close

\section{Full Screen / Esc}

Printer-friendly Version

Interactive Discussion 
Rogers, R. R.: Doppler Radar Investigation of Hawaiian Rain, Tellus, 19, 432-455, 1967.

Salles, C. and Poesen, J.: Performance of an optical spectro pluviometer in measuring basic rain erosivity characteristics, J. Hydrol., 218, 142-156, 1999.

Sheppard, B. E.: Measurement of Raindrop Size Distributions Using a Small Doppler Radar, J. Atmos. Ocean. Tech., 7, 255-268, 1990.

Stephens, G. L. and Kummerow, C. D.: The remote sensing of clouds and precipitation from space: A review, J. Atmos. Sci., 64, 3742-3765, 2007.

Tokay, A. and Short, D. A.: Evidence from tropical raindrop spectra of the origin of rain from stratiform versus convective clouds, J. Appl. Meteorol., 35, 355-371, 1996.

10 van Dijk, A., Bruijnzeel, L. A., and Rosewell, C. J.: Rainfall intensity-kinetic energy relationships: a critical literature appraisal, J. Hydrol., 261, 1-23, 2002.

Wiesner, J.: Contributions to the knowledge of the tropical rain. Sitzungsberichte der Mathematisch-Naturwissenschaftlichen Classe der Kaiserlichen Akademie der Wissenschaften, 104, 1397-1434, 1895.

\section{AMTD}

$4,6041-6068,2011$

\section{Rain research with}

disdrometers: a

bibliometric review

M. Fernandez-Raga et al.

Title Page

\section{Abstract}

Introduction

Conclusions

References

Tables

Figures

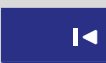

14

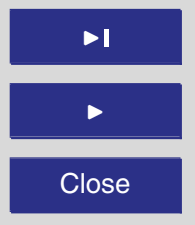

Back

Close

Full Screen / Esc

Printer-friendly Version

Interactive Discussion 
Table 1. Articles cited more than 30 times, and the number of times they are cited in the main journals.

\begin{tabular}{|c|c|c|c|c|c|c|c|c|}
\hline & & $\mathrm{K}$ & L & $\mathrm{R}$ & $\mathrm{N}$ & $\mathrm{P}$ & Q & $\mathrm{F}$ \\
\hline Adv. Water Res. & A & 9 & 2 & & & 2 & & \\
\hline Appl. Optics & $\mathrm{B}$ & 2 & & & & & & \\
\hline Asia-Pacific J. Atmos. Sci. & $\mathrm{C}$ & 2 & & & & & & \\
\hline Atmos. Res. & $\mathrm{D}$ & 17 & 8 & & & & 2 & \\
\hline Aust. J. Soil Res. & $\mathrm{E}$ & & & & & & & \\
\hline B. Am. Meteorol. Soc. & $\bar{F}$ & & 2 & 2 & & & & \\
\hline Catena & $\mathrm{G}$ & & & & & 5 & & \\
\hline Earth Surf. Process. Landforms & $\mathrm{H}$ & & & & & 2 & & \\
\hline Geophys. Res. Lett. & I & 5 & 4 & & 4 & & 2 & 2 \\
\hline Hydrol. Process. & $\mathrm{J}$ & & & & & 3 & & \\
\hline J. Appl. Meteorol. C. \& J. Appl. Meteorol. & $\mathrm{K}$ & 128 & 90 & 19 & 20 & & 5 & 7 \\
\hline J. Atmos. Ocean Tech. & $\mathrm{L}$ & 111 & 56 & 32 & 4 & & & 2 \\
\hline J. Clim. Appl. Meteorol. & M & 11 & & & & & & \\
\hline J. Geophys. Res. & $\mathrm{N}$ & 12 & 14 & 6 & 10 & & & 2 \\
\hline J. Hidrol. Eng. & $\mathrm{O}$ & 2 & & & & & & \\
\hline J. Hydrol. & $P$ & 17 & 5 & 4 & & 7 & 5 & 2 \\
\hline J. Hydrometeorol. & Q & 12 & 7 & & & & 4 & \\
\hline J. Atmos. Sci. & $\mathrm{R}$ & 33 & 25 & 16 & 3 & & 4 & 2 \\
\hline J. Korean Meteorol. Soc. & $\mathrm{S}$ & 4 & & & & & & \\
\hline J. Meteorol. Soc. Jpn. & $\mathrm{T}$ & 10 & 3 & & & & & \\
\hline Land Degrad. Dev. & $U$ & & & & & 2 & & \\
\hline Meteorol. Appl. & $\mathrm{V}$ & & 2 & & & & & \\
\hline Microwave J. & W & & & & 2 & & & \\
\hline Mon. Weather Rev. & $x$ & 27 & 7 & 4 & 4 & & 2 & \\
\hline Q. J. Roy. Meteor. Soc. & $\mathrm{Y}$ & 23 & 2 & 5 & & & 2 & 3 \\
\hline Radio Sci. & Z & 15 & & & 2 & & & \\
\hline Rev. Geophys. & AA & 3 & & & & & & \\
\hline Sci. Total Environ. & $A B$ & & & & & 2 & & \\
\hline Soil Sci. Soc. Am. J. & $\mathrm{AC}$ & & & & & 2 & & \\
\hline S. Afr. J. Sci. & $A D$ & & & & & 2 & & \\
\hline Water Resour. Res. & $\mathrm{AE}$ & 9 & & & & & 3 & \\
\hline Weather Forecast & AF & 4 & 5 & & 2 & & & \\
\hline
\end{tabular}

AMTD

$4,6041-6068,2011$

\section{Rain research with \\ disdrometers: a \\ bibliometric review}

M. Fernandez-Raga et al.

\section{Title Page}

\section{Abstract}

Introduction

Conclusions

References

Tables

Figures
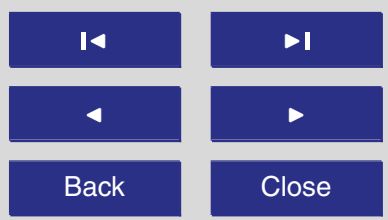

Back

Close

\section{Full Screen / Esc}

Printer-friendly Version

Interactive Discussion 


\section{AMTD}

4, 6041-6068, 2011

Table 2. Keywords that have been used more than 10 times, and the number of articles in which they appear.

\begin{tabular}{lc}
\hline Keywords & Number \\
\hline drop size distribution & 308 \\
radar & 61 \\
disdrometer & 64 \\
rainfall, rain, precipitation & 138 \\
shape & 40 \\
cloud & 31 \\
reflectivity & 29 \\
model & 27 \\
Doppler radar & 26 \\
precipitating systems & 25 \\
parameters & 17 \\
climatic, polarimetric & 16 \\
convection, differential phase & 13 \\
attenuation, axis ratios, stratiform, wind, reflectivity & 12 \\
weather, polarimetric radar & 11 \\
calibration, laboratory measurements, & 10 \\
variability, cloud, Joss-Waldvogel disdrometer & \\
\hline
\end{tabular}

\section{Rain research with disdrometers: a bibliometric review}

M. Fernandez-Raga et al.

Title Page

\section{Abstract}

Introduction

Conclusions

Tables

References

Figures

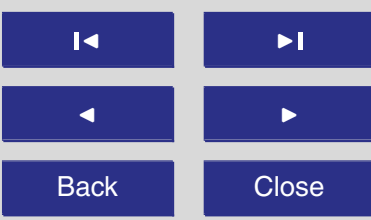

Full Screen / Esc

Printer-friendly Version

Interactive Discussion 


\section{AMTD}

4, 6041-6068, 2011

\section{Rain research with \\ disdrometers: a}

Table 3. Topics dealt with in articles on disdrometers.

\begin{tabular}{|c|c|c|c|c|}
\hline & Topic & First time used & Number of articles & Research line \\
\hline & radar & 1972 & 271 & meteorology \\
\hline & rainfall & 1972 & 241 & meteorology \\
\hline & raindrop & 1976 & 192 & meteorology \\
\hline & reflectivity & 1978 & 187 & meteorology \\
\hline & tropical & 1987 & 77 & meteorology \\
\hline & drop size distribution & 1991 & 194 & meteorology \\
\hline & Break-up & 1991 & 20 & meteorology \\
\hline Disdrometer* + & Vertical speed & 1991 & 30 & hydrology \\
\hline & modelling & 1991 & 121 & modelling \\
\hline & wind measurement & 1991 & 59 & meteorology \\
\hline & erosion & 1993 & 9 & erosion \\
\hline & kinetic energy & 1996 & 10 & erosion \\
\hline & convective & 1993 & 87 & modelling \\
\hline & stratiform & 1996 & 83 & modelling \\
\hline
\end{tabular}

\section{bibliometric review}

M. Fernandez-Raga et al.

Title Page

\section{Abstract}

Introduction

Conclusions

Tables

References

Figures
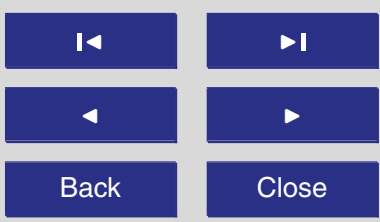

Full Screen / Esc

Printer-friendly Version

Interactive Discussion 


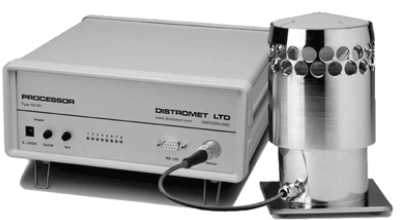

a)

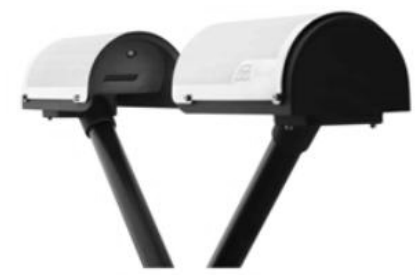

c)

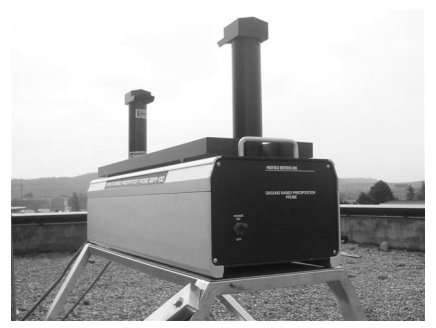

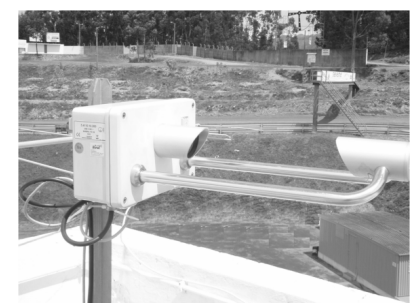

b)

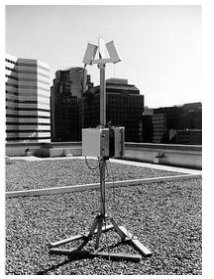

d)

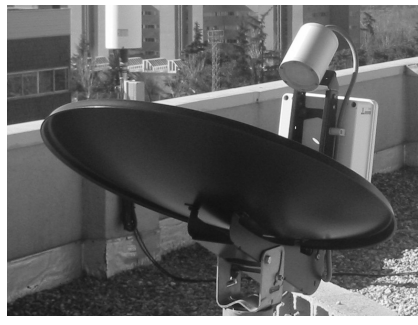

f)

Fig. 1. Some of the disdrometers used in rain research: (a) Joss-Waldvogel (photo from www.distromet.com); (b) Laser Precipitation Monitor (Thies Clima); (c) Parsivel Laser Optical Disdrometer (photo from www.hotfrog.es/Empresas/OTT-Medioambiente-Iberia_2621606/ OTT-Parsivel-22738), (d) Precipitation Occurrence Sensor System, POSS, (photo from www. radar.mcgill.ca/facilities/poss.html); (e) Ground Based Precipitation Probe, (f) Micro Rain Radar.

\section{AMTD}

4, 6041-6068, 2011

Rain research with

disdrometers: a

bibliometric review

M. Fernandez-Raga et al.

\section{Title Page}

Abstract

Introduction

Conclusions

References

Tables

Figures

14

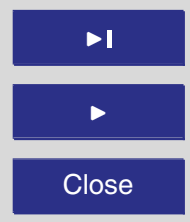

Back

Close

\section{Full Screen / Esc}

Printer-friendly Version

Interactive Discussion 
AMTD

$4,6041-6068,2011$

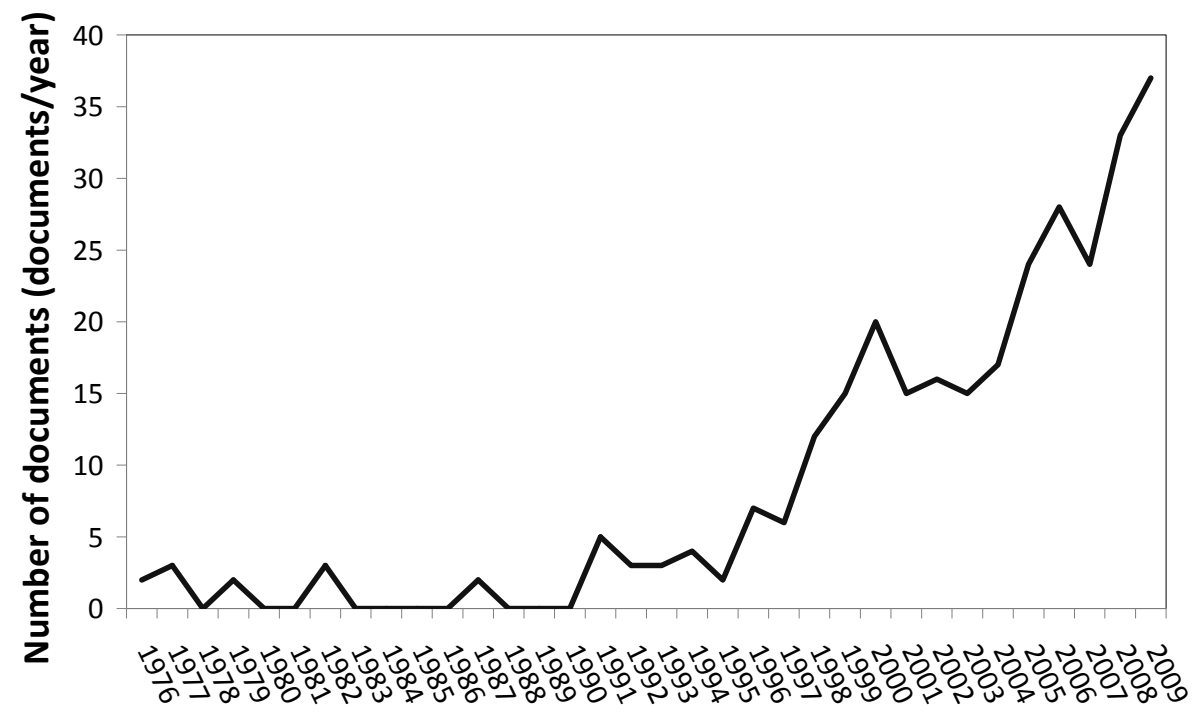

\section{Rain research with} disdrometers: a bibliometric review

M. Fernandez-Raga et al.

Title Page

Abstract

Introduction

Conclusions

References

Tables

Figures

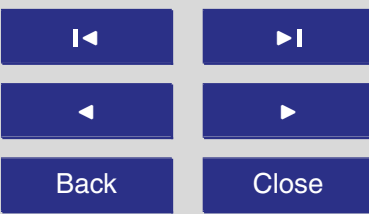

Full Screen / Esc

Fig. 2. Annual evolution of the number of documents on disdrometers.

Printer-friendly Version

Interactive Discussion 


\section{AMTD}

$4,6041-6068,2011$

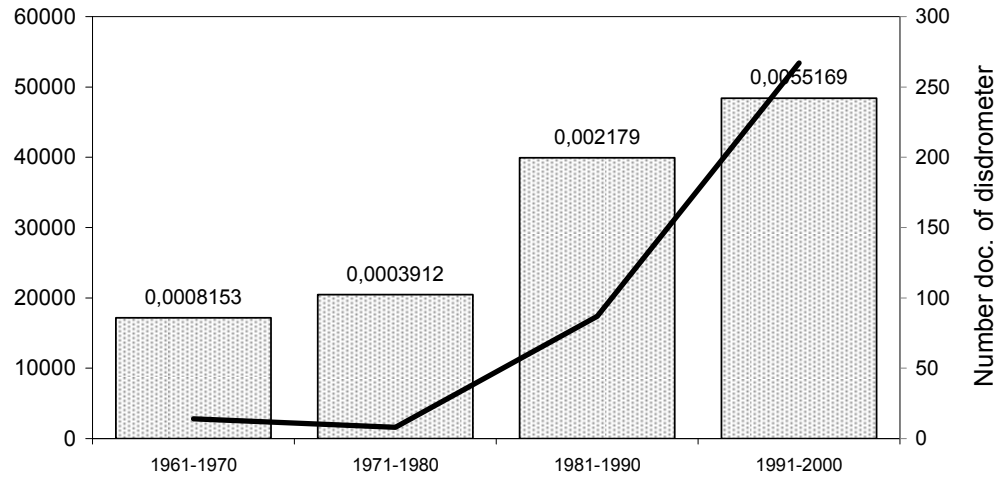

Rain research with

disdrometers: a

bibliometric review

M. Fernandez-Raga et al.

Title Page

\section{Abstract}

Conclusions

$\mathrm{N}^{\circ}$ doc. meteorology

Years

- ${ }^{\circ}$ doc.disdrometer

Fig. 3. Ten-yearly evolution of the number of documents on disdrometers and the number of documents on Meteorology and Atmospheric Sciences. The numbers in the upper border indicate the ratio between both in each decade.
Tables

\section{Introduction}

References

Figures

14

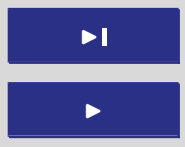

Back

Close

Full Screen / Esc

Printer-friendly Version

Interactive Discussion 


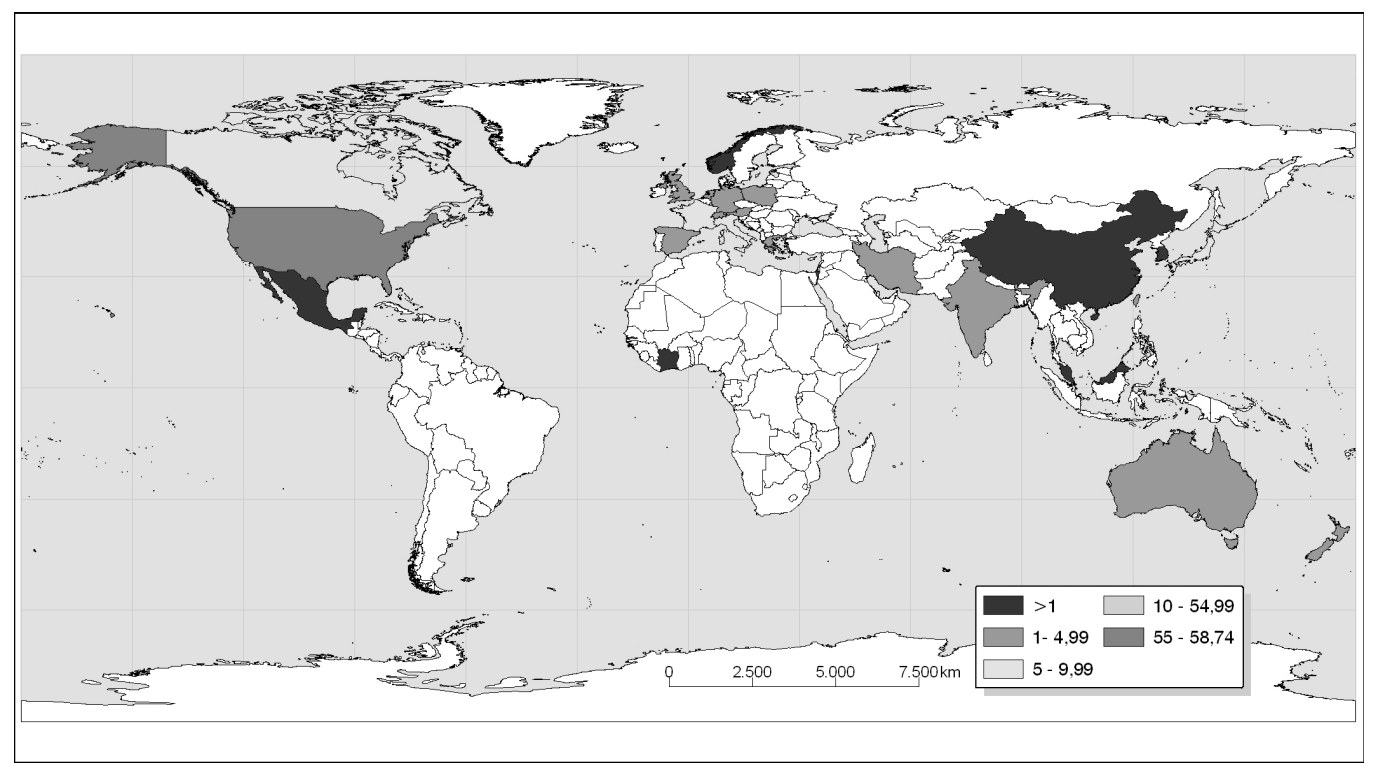

Fig. 4. Countries that have published on the use of the disdrometer, and their respective percentage.

\section{AMTD}

4, 6041-6068, 2011

\section{Rain research with disdrometers: a bibliometric review}

M. Fernandez-Raga et al.

\section{Title Page}

Abstract

Introduction

Conclusions

References

Tables

Figures

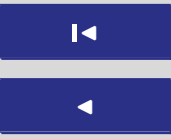

Back

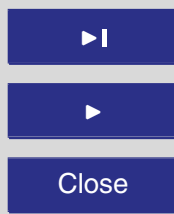

Full Screen / Esc

Printer-friendly Version

Interactive Discussion

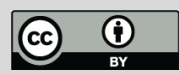




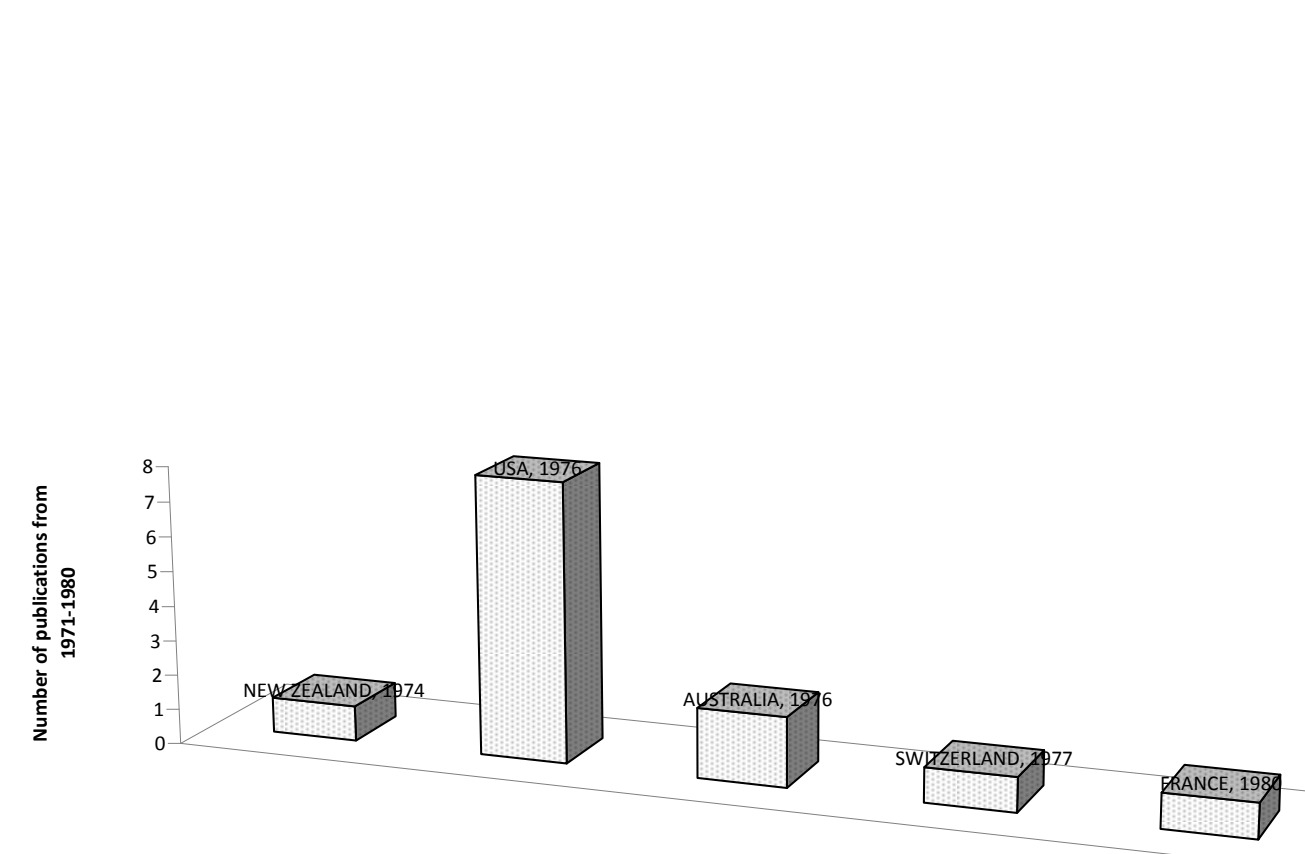

AMTD

4, 6041-6068, 2011

\section{Rain research with \\ disdrometers: a bibliometric review}

M. Fernandez-Raga et al.

Title Page

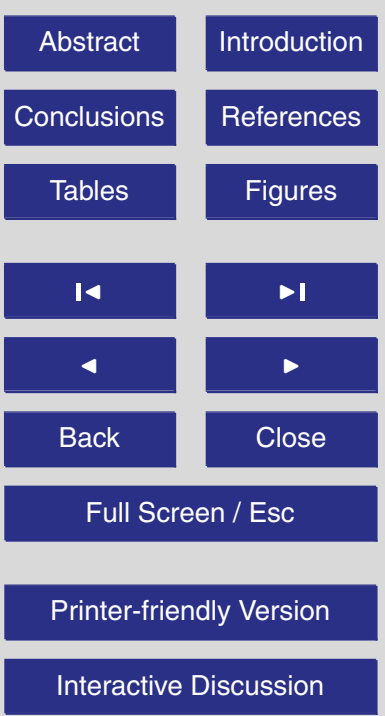

Fig. 5. The first five countries to publish studies carried out with disdrometers, and the year of the first publication. 


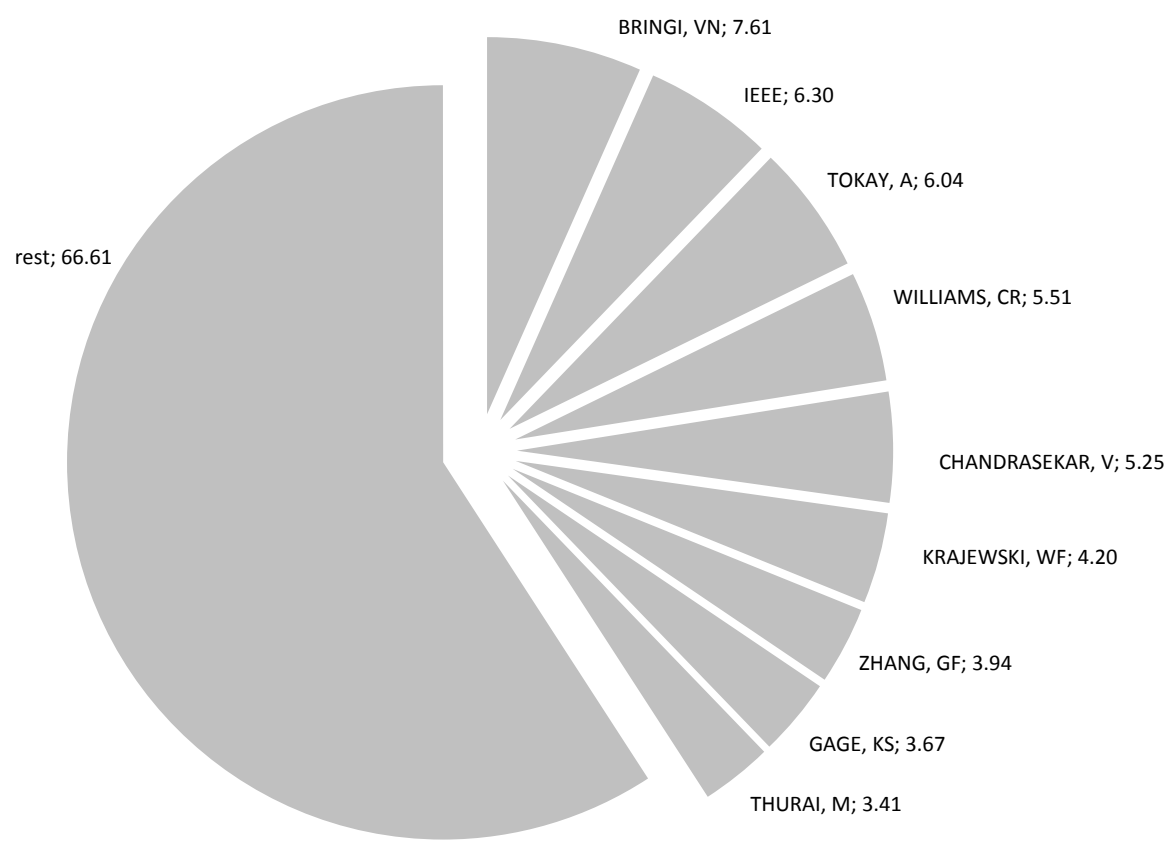

Fig. 6. Authors with the largest number of publications, together with the percentage of articles in relation to the total.

\section{Rain research with disdrometers: a bibliometric review}

M. Fernandez-Raga et al.

Title Page

\begin{tabular}{|c|c|}
\hline Abstract & Introduction \\
\hline Conclusions & References \\
\hline Tables & Figures \\
\hline I4 & $\bullet \mathbf{I}$ \\
\hline 4 & $\triangleright$ \\
\hline Back & Close \\
\hline Full Screen / Esc \\
\hline
\end{tabular}

Printer-friendly Version

Interactive Discussion 


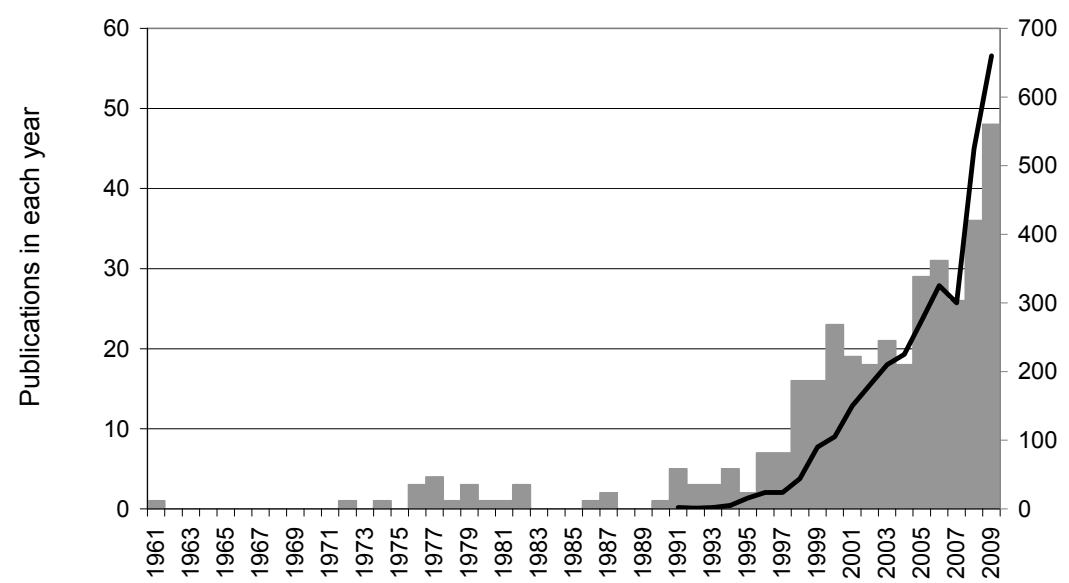

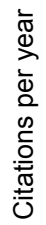

Years

$\mathrm{n}^{\circ}$ publications

- citations

Fig. 7. Number of publications and citations per year in relation to articles in which disdrometer are used.
AMTD

4, 6041-6068, 2011

\section{Rain research with disdrometers: a bibliometric review}

M. Fernandez-Raga et al.

Title Page

Abstract

Introduction

Conclusions

References

Tables

Figures

14

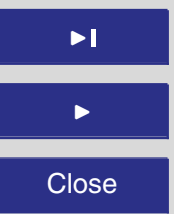

Back

Close

Full Screen / Esc

Printer-friendly Version

Interactive Discussion

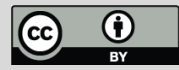




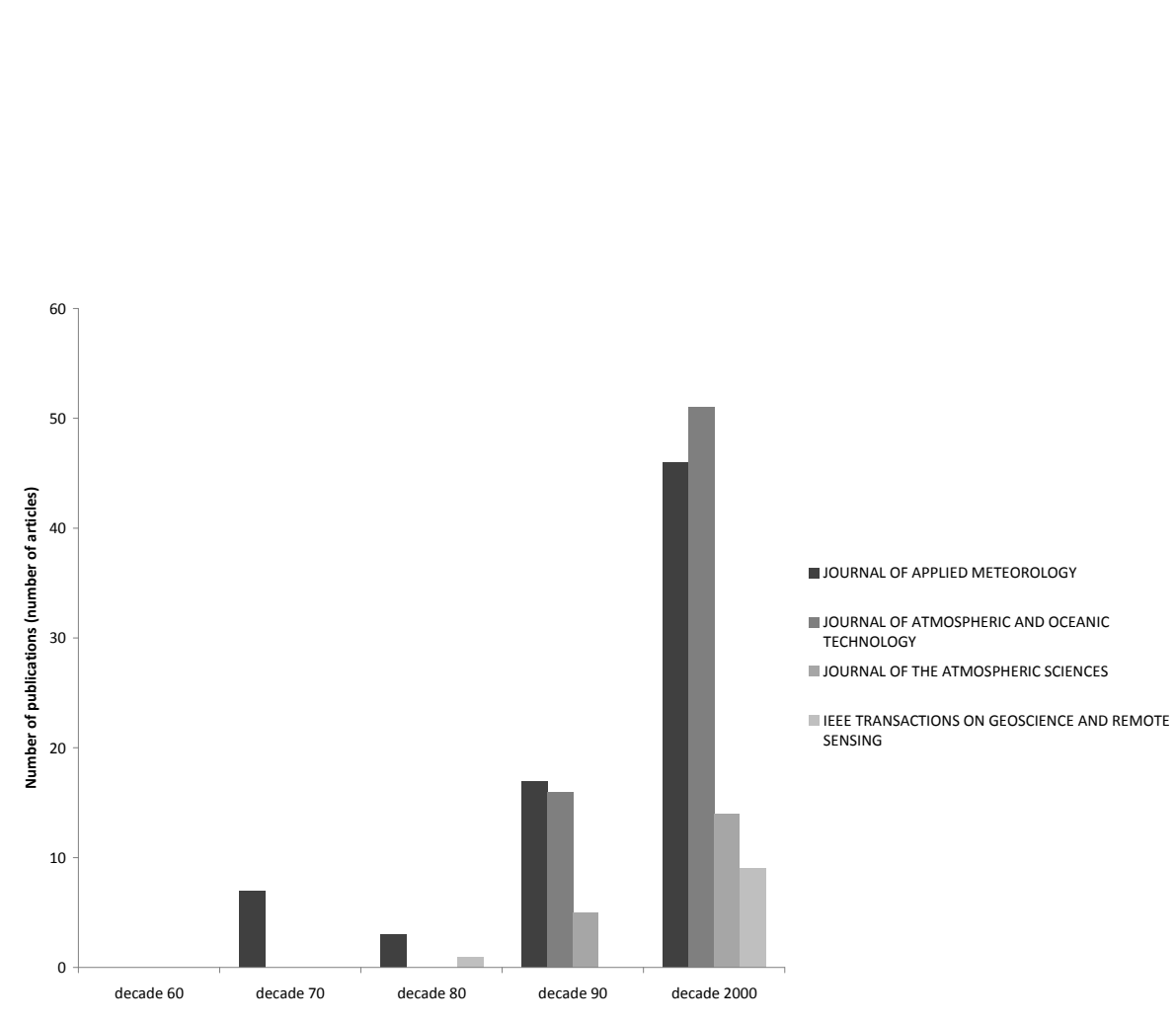

Fig. 8. Number of publications per decade from the 4 journals with the largest number of publications in which disdrometers are used.

AMTD

$4,6041-6068,2011$

\section{Rain research with \\ disdrometers: a \\ bibliometric review}

M. Fernandez-Raga et al.

Title Page
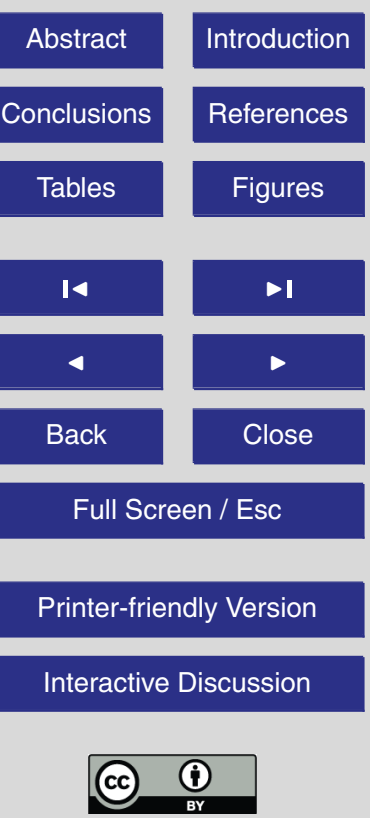